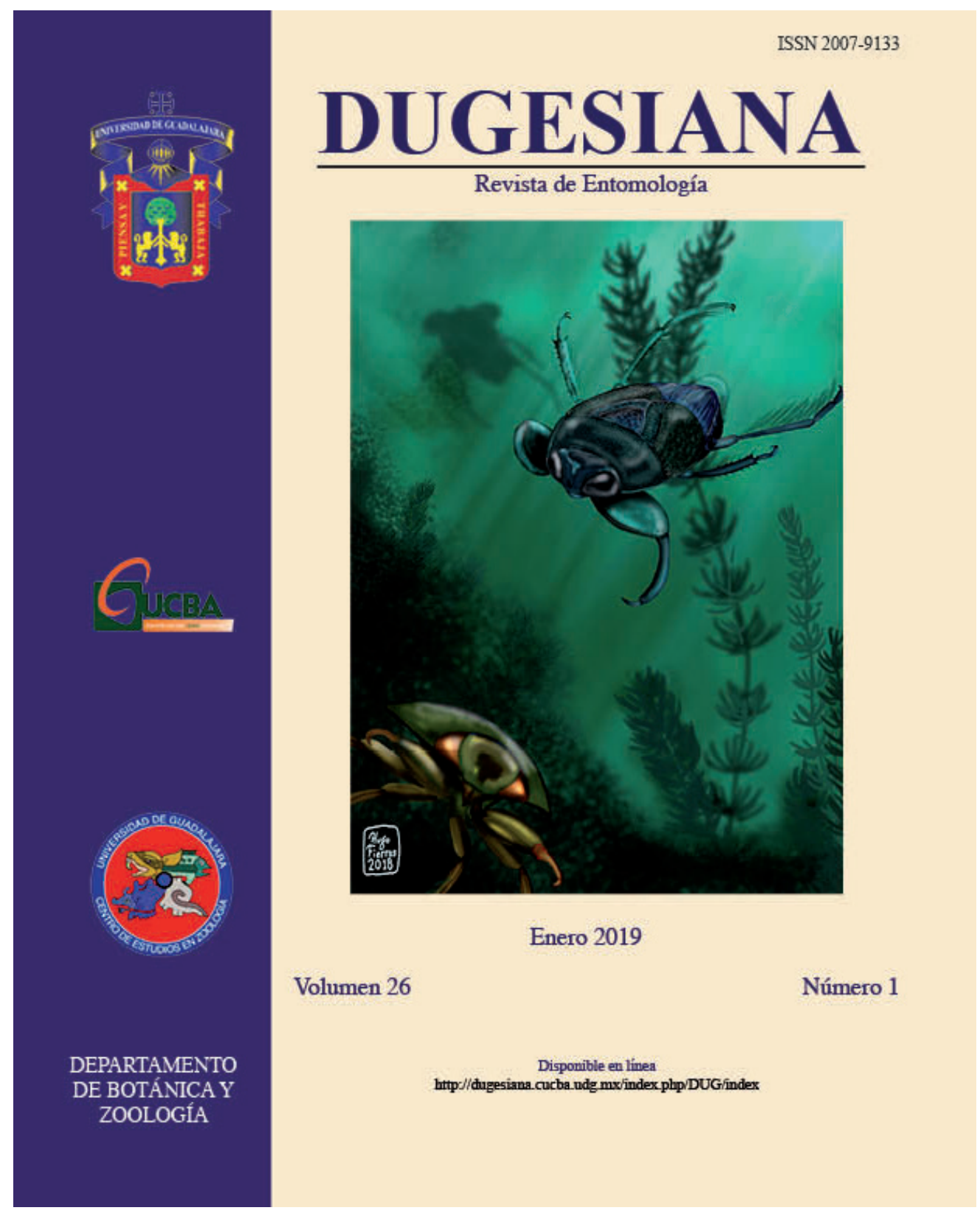

DUGESIANA, Año 26, No.1, 2019 (primer semestre de 2019) es una publicación Semestral editada por la Universidad de Guadalajara, a través del Centro de Estudios en Zoología, por la División de Ciencias Biológicas y Ambientales, CUCBA. Km. 15.5 carr. a Nogales, Predio Las Agujas s/n, Nextipac, C.P. 45100. Zapopan, Jalisco, México. Tel. 37771150, http://dugesiana.cucba.udg.mx/index.php/DUG/index, glenusmx@gmail.com, Editor responsable: José Luis Navarrete Heredia. Reserva de Derechos al Uso Exclusivo 04-2009-062310115100-203, ISSN: 2007-9133, otorgados por el Instituto Nacional del Derecho de Autor. Responsable de la última actualización de este número: José Luis Navarrete Heredia, Editor y Ana Laura González-Hernández, Asistente Editorial. Fecha de la última modificación 1 de enero de 2019, con un tiraje de un ejemplar.

Las opiniones expresadas por los autores no necesariamente reflejan la postura del editor de la publicación.

Queda estrictamente prohibida la reproducción total o parcial de los contenidos e imágenes de la publicación sin previa autorización de la Universidad de Guadalajara. 


\title{
Chaetocoelus moroni sp. nov. (Coleoptera: Melyridae) de Oaxaca, México
}

\section{Chaetocoelus moroni sp. nov. (Coleoptera: Melyridae) of Oaxaca, Mexico}

\author{
Santiago Zaragoza-Caballero ${ }^{1}$ y Viridiana Vega-Badillo, ${ }^{1,2}$ \\ 'Departamento de Zoología, Instituto de Biología, Universidad Nacional Autónoma de México. Apartado Postal \\ 70-153, 04310 CdMx, México. 'E-mail zaragoza@ib.unam.mx; ${ }^{2}$ Posgrado en Ciencias Biológicas, Universidad \\ Nacional Autónoma de México, Apartado Postal 70-153, 04310 CdMx, México.
}

\section{RESUMEN}

Se describe una nueva especie, Chaetocoelus moroni sp. nov. procedente del estado de Oaxaca, México. Se compara con $C$. setosus. Representa la segunda especie de dicho género entre los coleópteros Melyridae.

Palabras clave: Insecta, Malachiinae: Carphurini sp. nov., México

\begin{abstract}
the second species of this genus among the coleoptera Melyridae.
Keywords: Insecta, Malachiinae: Carphurini sp. nov., Mexico.

El género Chaetocoelus, descrito originalmente por LeConte en 1880, se reconoce por la siguiente combinación de caracteres: cabeza corta, frente con impresiones ligeras, clípeo corto, aparentemente membranoso; sutura epistomal tangente a las fosetas antenales. Antenas de 11 segmentos, submoniliformes a subserradas. Pronoto cuadrado, tan ancho como la cabeza, ángulos anteriores variables, ángulos posteriores redondeados, disco pronotal liso. Élitros, totalmente desarrollados en machos, reducidos en hembras, ápice redondo en ambos sexos. Alas membranosas totalmente desarrolladas en machos, reducidas en hembras. Formula tarsal 5-5-5; el primer tarsómero del protarso masculino con un peine robusto, en el margen interior: tarsómeros 2-4 en ambos sexos angostos, ápice redondeado no bilobulado. Esternitos parcialmente esclerotizados, el último redondeado en ambos sexos, pigidio truncado en machos y redondeado en hembras. Edeago con el lóbulo medio alargado, apicalmente bilobulado, saco interno provisto con grandes espinas agudas (Mayor, 1982). Adicionando la especie descrita en el presente trabajo el género queda integrado por dos especies, una de ellas presente en el sureste de Norte América, desde Florida hasta el oeste de Texas, otra en Oaxaca, México.
\end{abstract}

ABSTRACT

A new species of the genus Chaetocoelus is described from the state of Oaxaca, Mexico. It is compared with C. setosus. It represents

\section{MATERIALES Y MÉTODOS}

El ejemplar de estudio se recuperó de un frasco recolector de una trampa de intercepción colocada en el sotobosque a 1.56 de altura. Fue fijado en alcohol $70 \%$, para preservarlo se montó en una laminilla en euparal. Se le tomaron medidas de largo y ancho total, largo y ancho del pronoto, largo y ancho de los élitros, distancia interocular e interantenal, largo y ancho de los ojos, así como la longitud de los once antenitos. Las imágenes se lograron con la ayuda de una cámara Axio Cam Mrec5 adaptada a un microscopio Zeiss AXIO Zoom V16 y procesadas con el programa ZEM, Zeiss eficient navigation. Las medidas se expresan en milímetros.

\section{Chaetocoelus moroni sp. nov.}

Figuras 1-6

http://zoobank.org/025185C3-853F-491E-81B06D4FECAFB711

Diagnosis. Esta especie se relaciona con C. setosus, de la que puede diferenciarse por el largo de las antenas, las dimensiones del pronoto, así como el número de espinas que integran el peine protarsal (Cuadro 1).

Holotipo macho. (Figs. 1, 2). Largo 3.69; ancho 0.62. Cuerpo alargado, aplanado en sentido dorso-ventral, de color pardo-obscuro, élitros y abdomen más claros. Cabeza. Casi tan larga como ancha (0.58X0.58) a nivel de los ojos, posteriormente más angosta (Figs. 3, 4), integumento chagrinado, y unas cuantas sedas a los lados, con hileras de puntos, más densas cercanas a los ojos y cuatro estrías transversales en la región occipital, tubérculos anteníferos poco prominentes; antenas interiormente serradas, con 11 antenitos, el escapo de forma clavada y 0.11 de largo, del segundo al décimo antenito de 0.12 , el undécimo de 0.16 ; distancia interantenal (0.19); ojos semiesféricos, granulosamente facetados, más largos que anchos (0.20X0.12), separados por dos veces lo ancho del ojo; frente declivente; clípeo indistinto; mandíbulas anchas, robustas, la derecha con dos dientes, el apical agudo, la izquierda con tres dientes los dos basales triangulares, el apical agudo; último palpómero maxilar acuminado, tan largo como el primero; el palpómero labial apical, casi cuadrado, tan largo como ancho; tentorio con una fosita en la base de las piezas bucales. Tórax. Pronoto un poco más ancho que largo (0.49X0.43), ligeramente más ancho en la mitad anterior, borde anterior y posterior cóncavo, lo mismo que los bordes laterales, integumento con unas pocas sedas (Figs. 1, 2); escutelo tan largo como ancho, borde posterior romo; élitros casi paralelos, cortos, rebasando un poco el segundo terguito, casi cuatro veces más largos que anchos (1.61X0.43), ápice redondo, espaciadamente cubierto por sedas erectas; alas membranosas con la venación reducida; 
prosterno corto, con el borde anterior cóncavo, el posterior bituberculado, cavidades coxales anteriores abiertas, borde anterior del mesosterno profundamente cóncavo, ángulos anteriores agudos (Fig. 2), el borde posterior proyectado en un ápice romo; metasterno piriforme, angosto en la parte anterior; patas largas, las anteriores más cortas, tibias con dos espinas apicales, primer tarsómero de la pata anterior con un peine que cubre toda la superficie ventral, primer tarsómero de las patas medias y posteriores de igual longitud que los dos siguiente tarsómeros juntos, uñas simples. Abdomen. Con siete segmentos, los posteriores más angostos, cubiertos por largas sedas, más visibles a los lados, pigidio con el borde posterior cóncavo, ángulos posteriores agudos (Figs. 1-2); edeago (Fig. 6) tipo trilobulado con la pieza basal muy desarrollada, lóbulos laterales cortos cubriendo dorsalmente al lóbulo medio, éste alargado, casi paralelo, con un canal eyaculador.

Etimología: moroni, epíteto dedicado con mucho respeto y admiración al eminente Dr. Miguel Ángel Morón Ríos, primer tesista del primer autor, a quien le brindó la satisfacción de verlo crecer académicamente.

Recibido: 25 de septiembre de 2018

Aceptado: 26 de octubre de 2018

Primero en línea: 26 de noviembre 2018

Online First Publication: 26th November 2018

Cuadro1. Comparación entre Chaetocoelus setosus y C. moroni

Chaetocoelus setosus LeConte

Antenas cortas, ligeramente sobrepasando el hombro elitral.

Séptimo antenómero tan largo como ancho. 0.8X1.0

Pronoto tan ancho como largo. 0.78

Peine del protarso, integrado por siete espinas.
Holotipo macho etiquetado: México, Oaxaca: Santa María Pápalo N17.81984; W96.79201, 2,428 msnm, 21-abril-2015, trampa de intercepción de vuelo $1.56 \mathrm{mts}$. col. Valeria Guzmán. Depositado en la Colección Nacional de insectos (CNIN) de la Universidad Nacional Autónoma de México, (COL.TIP-03599).

\section{AGRADECIMIENTOS}

A José Luis Navarrete-Heredia por su invitación a esta contribución que rinde un homenaje póstumo a los doctores Miguel Ángel Morón Ríos y Pedro Reyes Castillo, entomólogos de renombre internacional que se dedicaron de siempre al estudio de los escarabajos lamelicornios.

A Michael Ivie y a Adriean Mayor por aclarar la posición taxonómica de la especie en cuestión. A Valeria Guzmán la recolección del ejemplar tipo.

\section{LITERATURA CITADA}

LeConte, J. 1880. Short studies of North American Coleoptera. Transactions of the American Entomological Society 8:194.

Mayor, A. J. 1982 A review of the genus Chaetocoelus LeConte (Coleoptera: Malachiidae). Proceedings of the Entomological Society of Washington. 84(3): 475-479.

\begin{tabular}{|l|l|}
\hline \multicolumn{1}{|c|}{ Chaetocoelus setosus LeConte } & \multicolumn{1}{c|}{ Chaetocoelus moroni sp. nov. } \\
$\begin{array}{l}\text { Antenas cortas, ligeramente sobrepasando el hombro } \\
\text { elitral. }\end{array}$ & Antenas largas, rebasando la mitad del élitro. \\
Séptimo antenómero tan largo como ancho. 0.8X1.0 & $\begin{array}{l}\text { Séptimo antenómero dos veces más largo que ancho. } \\
0.15 \mathrm{X} 0.07\end{array}$ \\
Pronoto tan ancho como largo. 0.78 & $\begin{array}{l}\text { Pronoto más ancho que largo. } 0.51 \mathrm{X} 0.41 \\
\text { Peine del protarso, integrado por siete espinas. }\end{array}$ \\
\hline
\end{tabular}



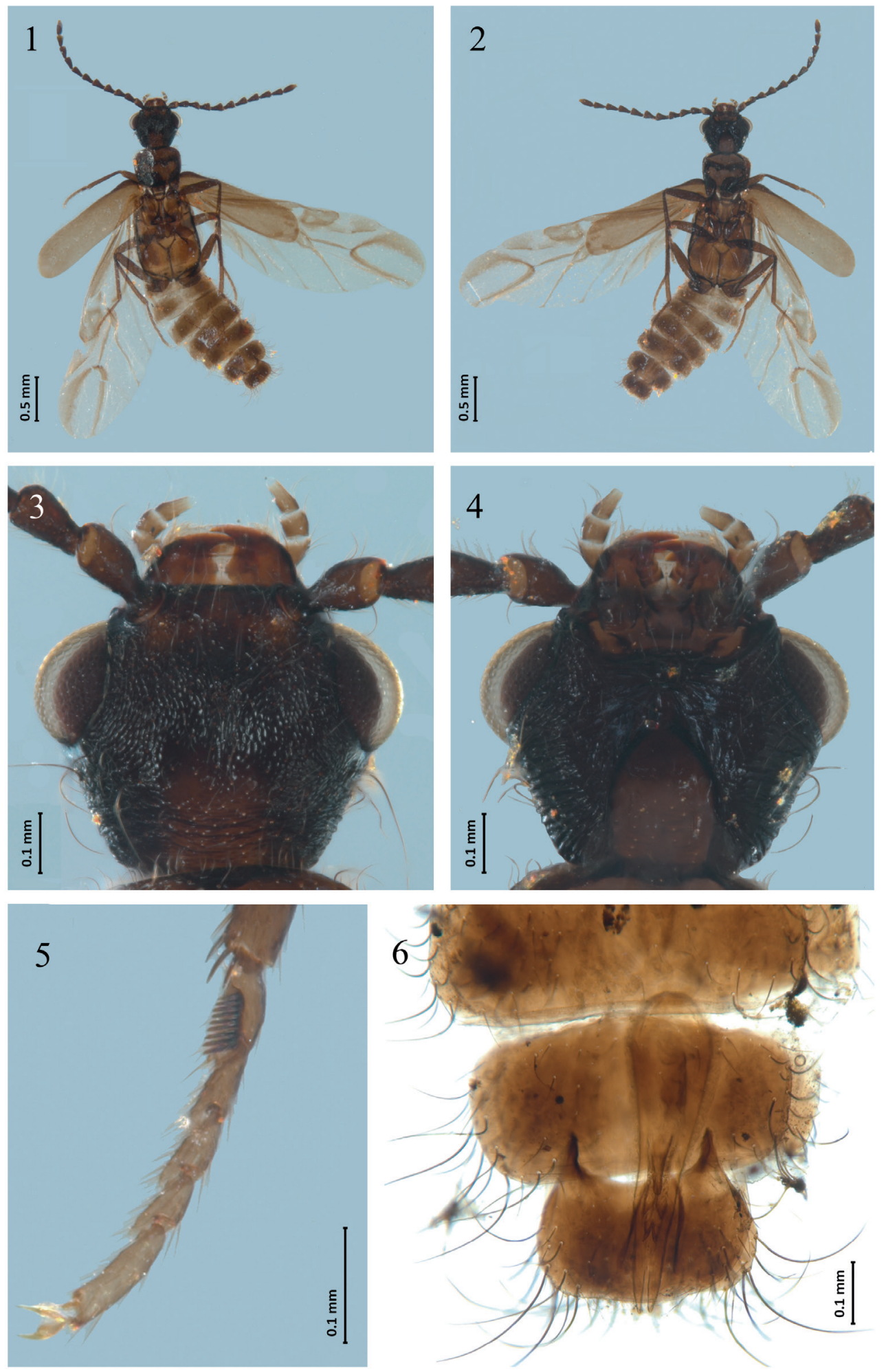

Figuras 1-6 de Chaetocoelus moroni sp. nov. Figs. 1-2.- Vista ventral y dorsal. Figs. 3-4, Vista dorsal y ventral de la cabeza. Fig. 5.- Vista lateral del peine del primer tarsómero de la pata anterior. Fig. 6.- Vista ventral (por transparencia) del aparato reproductor masculino. 